\title{
Heart broken twice: a case of recurrent Takatsubo cardiomyopathy
}

\author{
Kamal Kant Sahu (ㄷ, ${ }^{1}$ Ajay Kumar Mishra, ${ }^{1}$ Adhirath Doshi, ${ }^{2}$ Kevin B Martin ${ }^{3}$
}

${ }^{1}$ Department of Internal Medicine, Saint Vincent Hospital, Worcester, Massachusetts, USA ${ }^{2}$ Division of Cardiology, Saint Vincent Hospital, Worcester, Massachusetts, USA ${ }^{3}$ Pulmonary Division, Reliant Medical Group, Saint Vincent Hospital, Worcester, Massachusetts, USA

\section{Correspondence to} Dr Kamal Kant Sahu; drkksahu85@gmail.com

Accepted 5 December 2019

Check for updates

(c) BMJ Publishing Group Limited 2020. No commercial re-use. See rights and permissions. Published by BMJ.

To cite: Sahu KK, Mishra AK, Doshi A, et al. BMJ Case Rep 2020;13:e232253. doi:10.1136/bcr-2019232253

\section{DESCRIPTION}

A 53-year-old woman with a past medical history of diabetes, hypertension, persistent atrial fibrillation on anticoagulation and resolved takotsubo cardiomyopathy (TTC) 2 years ago presented with 2 days of dyspnoea, fever and dysuria. Her vitals were blood pressure- $90 / 60 \mathrm{~mm} \mathrm{Hg}$, pulse rate$110 /$ min, irregular rhythm, respiratory rate-16/ min and $\mathrm{SPO}_{2}-90 \%$ on room air. Examination was positive for use of accessory muscles of respiration, bilateral coarse crackles over the lung bases and pedal oedema $2+$ up to the knees. Laboratory work showed leucocyte count of $12.3 \times 10^{9} / \mathrm{L}$, urine culture grew Escherichia coli and chest X-ray showed bilateral pleural effusion. Hence, diagnosis of sepsis due to urinary tract infection, congestive heart failure and atrial fibrillation with fast ventricular rate was made. She was started on intravenous ceftriaxone. Her fever and tachycardia responded within next 24 hours, but she continued to have hypotension and hypoxia. A transthoracic echocardiography showed a low ejection fraction of $15 \%$, mild mitral regurgitation, with systolic apical ballooning of the left ventricle and hyperkinesis of the basal walls (figure 1). She suffered a stressinduced cardiomyopathy 2 years back with stressor being sudden death of both the parents. At that time, she was initiated on beta-blockers, following which the ejection fraction improved. Based on combined history of TTC, the classical echo findings and physical stress of urinary tract infection, the diagnosis of recurrent TTC was made at this admission. She was initiated on metoprolol succinate and lisinopril at tolerable doses. For E. colirelated urinary tract infection, she finished 7 days of antibiotics. A follow-up two-dimensional echo showed an improved ejection fraction to $40 \%$.

Takotsubo syndrome is a rare acute cardiac crisis event that frequently is headed by a stressful trigger.
In our case, patient had both emotional (first event) and physical trauma (second event). Classically, emotional or physical stress triggers an excessive sympathetic nervous system stimulation responsible for TTC. Nyman et al recently did a systematic review on trigger factors in TTC and found that physical factors are more common than emotional factors. ${ }^{1}$ Also, they found that most vulnerable group to have evident trigger factors leading to TTC are women $\leq 50$ years of age and men. The review consisted of 1330 TTC cases, out of which 1112 cases $(83.6 \%)$ had at least one trigger factor with $67.3 \%$ physical and $32.7 \%$ emotional factor. Most common physical factor was illness (60\%) followed by procedure/surgery-related stress $(40 \%)$. Similarly, anxiety/panic attack/fear (31.6\%) constituted the most common emotional trigger followed by grief/loss (23.1\%). ${ }^{1}$ Some of the commonly reported physical triggers are chronic obstructive pulmonary disease, subarachnoid haemorrhage, thyrotoxicosis, Addisonian crisis, sepsis and so on. ${ }^{1}$ In addition, recently Amariles et al reviewed literature and reported at least 20 drugs that were recognised as possible cause for drug induced TTC. ${ }^{2}$ Recently, Auger et al also found TTC to have an association with autoimmune disease, pneumonia, renal disease, mental disorders as compared with population controls. ${ }^{3}$ Although, no well-established literature is available to date, but recently electrolyte imbalances especially hypomagnesaemia and hypocalcaemia have been linked to TTC. ${ }^{4}$ Role of electrolyte imbalances as a trigger factor needs to be confirmed through well-designed trials. Despite vigilant search no known trigger factor is found in approximately $30 \%$ of the TTC cases. ${ }^{5}$

It is characterised by transient ventricular wall dysfunction in the absence of coronary artery disease. ${ }^{6}$ This relatively rare condition $(<2 \%$ of ACSs in women and just $0.2 \%$ in men) is not
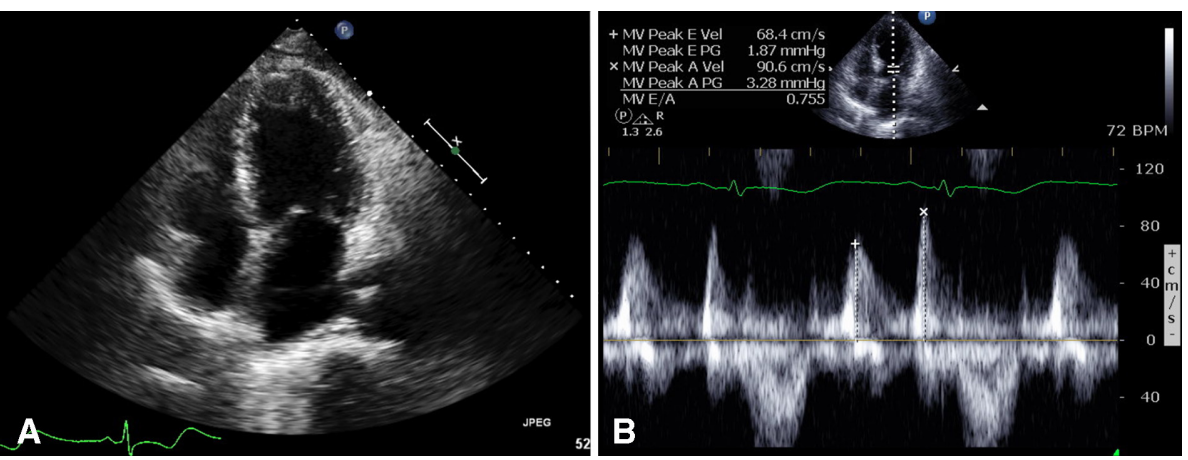

Figure 1 (A) Apical four chamber view showing ballooning of the apical segment of the left ventricle and (B) mitral regurgitation. 
often recognised initially because either symptoms are too mild and very non-specific. ${ }^{7}$ Recurrence is even further uncommon, reported only in 5\%-6\% of TTC cases. Interestingly, the risk of recurrence is maximum during initial years and gradually declines thereafter. Elesber et al reported the highest 2.9\% in the first 4 years and $1.3 \%$ thereafter. $^{8}$ The most widely accepted proposition for TTC is due to catecholamine surges secondary to stress. ${ }^{6}$ Varying beta receptor densities lead to differential effect on myocardium with resultant apical ballooning. However, the role of hormonal influences and innate susceptibility remain elusive. Clinical significance of recurrence of TTC is not clear due to sparse literature and probable under reporting. But there is increasing evidence that TTC is not a benign disease as various complications like ventricular arrythmias, cardiogenic shock has been reported. Knowledge about rare cardiac entities and their complications is of utmost importance for timely diagnosis and management. ${ }^{910}$

\section{Learning points}

- Takatsubo cardiomyopathy (TTC) is a rare entity and has classical echo findings.

- Recurrence of TTC is rare and recurrence rate decreases with time.

- TTC is not a benign entity and conduction abnormalities like ventricular arrhythmias can occur.

Contributors KKS: case writing, review and proofread. AM: case writing. AD: literature review. KM: management and critical review.
Funding The authors have not declared a specific grant for this research from any funding agency in the public, commercial or not-for-profit sectors.

Competing interests None declared.

Patient consent for publication Obtained.

Provenance and peer review Not commissioned; externally peer reviewed.

ORCID iD

Kamal Kant Sahu http://orcid.org/0000-0002-0382-6882

\section{REFERENCES}

1 Nyman E, Mattsson E, Tornvall P. Trigger factors in takotsubo syndrome - a systematic review of case reports. Eur J Intern Med 2019;63:62-8.

2 Amariles P. A comprehensive literature search: drugs as possible triggers of takotsubo cardiomyopathy. Curr Clin Pharmacol 2011;6:1-11.

3 Auger N, Paradis G, Healy-Profitós J, et al. Outcomes of takotsubo syndrome at 15 years: a matched cohort study. Am J Med 2019:308769.

4 Andreozzi F, Cuminetti G, Karmali R, et al. Electrolyte disorders as triggers for takotsubo cardiomyopathy. Eur J Case Rep Intern Med 2018;5:000760.

5 Templin C, Ghadri JR, Diekmann J, et al. Clinical features and outcomes of takotsubo (stress) cardiomyopathy. N Engl J Med 2015;373:929-38.

6 Korabathina R, Porcadas J, Mishkin M, et al. Three episodes of takotsubo cardiomyopathy with variant ballooning patterns in 2 elderly women. Tex Heart Inst $J$ 2018;45:247-51.

7 Elesber AA, Prasad A, Lennon RJ, et al. Four-Year recurrence rate and prognosis of the apical ballooning syndrome. J Am Coll Cardiol 2007;50:448-52.

8 Hasdemir C, Vuran O, Yuksel A, et al. Stress cardiomyopathy (Tako-Tsubo) associated with sustained polymorphic ventricular tachycardia. Pacing Clin Electrophysiol 2013;36:e111-4.

9 Dalia T, Masoomi R, Sahu KK, et al. Cardiac tamponade causing severe reversible hyponatraemia. BMJ Case Rep 201810.1136/bcr-2017-222949. [Epub ahead of print: 03 Jan 2018].

10 Mishra AK, Nadadur S, Sahu KK, et al. Penetrating aortic ulcer masquerading as acute coronary syndrome. Am J Med Sci 2019;358:e15-16.

Copyright 2020 BMJ Publishing Group. All rights reserved. For permission to reuse any of this content visit

https://www.bmj.com/company/products-services/rights-and-licensing/permissions/

BMJ Case Report Fellows may re-use this article for personal use and teaching without any further permission.

Become a Fellow of BMJ Case Reports today and you can:

- Submit as many cases as you like

- Enjoy fast sympathetic peer review and rapid publication of accepted articles

- Access all the published articles

- Re-use any of the published material for personal use and teaching without further permission

Customer Service

If you have any further queries about your subscription, please contact our customer services team on +44 (0) 2071111105 or via email at support@bmj.com.

Visit casereports.bmj.com for more articles like this and to become a Fellow 